\title{
Література
}

1. Бодалев А. А. Некоторые вопросы комплексного подхода к совершенствованию системы подготовки учителя в педвузе / А. Бодалев; в кн.: О системах и системности в воспитании. - Ч. 2. - М., 1986. - 166 с.

2. Борлак О. Використання інформаційних технологій у підготовці висококваліфікованих робітників / О. Борлак, Т. Нерода // Професійно-технічна освіта. 2002. - № 3. - C. 21-23.

3. Інформаційні технології у професійній підготовці майбутніх вчителів трудового навчання:[ монографія] / О.М. Торубара. - Чернігів: ЧДПУ, 2009. - 304 с.

4. Інформаційне забезпечення вищої школи України / Володимир Луговий, Наталія Халікян // Вища освіта України. - 2007. - № 3. - С. 48-51.

5. Сидоренко В.К. Підвищення якості навчання учнів ПТНЗ засобами інформаційнокомунікаційних технологій / В. Сидоренко, Н. Тверезовська // Проблеми інженернопедагогічної освіти : [зб. наук. праць]. - Випуск 13. - Х. : УІПА. - 2006. - С. 12-21.

6. Сидоренко В.К. Умови забезпечення навчальної діяльності учнів профтехучилищ засобами інформаційних технологій / В.К. Сидоренко // Інформаційнотелекомунікаційні технології в сучасній освіті: досвід, проблеми, перспективи : [зб. наук. праць] - Львів: ЛДУ БЖД, 2006. - С. 86-91.

7. Торубара О.М. Використання засобів новітніх інформаційних технологій в системі розвитку творчих здібностей учнів / О.М. Торубара // Освітянські обрії: реалії та перспективи: [зб. наук. праць] / Н.Т. Тверезовська (голова) та ін. - К. : ІПТО, 2007. - №1 C. $429-431$.

Стаття надійшла до редакції 12.05.2012 p.

УДК 37.013 .42

Н. Л. Сеньовська,

кандидат пед. наук, асистент,

Тернопільський національний педагогічний університет

імені В. Гнатюка

\section{ГЕНДЕРНИЙ ПІДХІД У СЕРЕДНІЙ ОСВІТІ (НА МАТЕРІАЛІ ВИВЧЕННЯ ДРАМАТУРГІЇ ЛЕСІ УКРАЇНКИ В 10 КЛАСІ)}

Сеньовська Н. Л. Гендерний підхід у середній освіті (на матеріалі вивчення драматургії Лесі Украӥнки в 10 класі).

У статті охарактеризовано тендерний підхід у середній освіті, щзо полягає як у тиражуванні наявних тендерних стереотипів, так і в просуванні ідей тендерної рівності. Описано тендерний аналіз драматичних поем Лесі Українки як один із засобів корекції процесу сойіалізації молоді залежно від статі.

Ключові слова: тендер, тендерні стереотипи, тендерний підхід в освіті, гендерний аспект вивчення драматичних творів.

Сеневская Н.Л. Гендерный подход в среднем образовании (на материале изучения драматургии Леси Украинки в 10 классе).

В статье охарактеризирован гендерный подход в среднем образовании, который заключается как в тиражировании имеющихся гендерных стереотипов, так и в продвижении идей гендерного равенства. Описан гендерный анализ драматических поэм Леси Украинки как одно из средств коррекиии процесса сочиализащии юномества в зависимости от пола.

Ключевые слова: гендер, гендерные стереотипь, гендерный подход в образовании, гендерный аспект изучения драматических произведений.

Senevskaya N. Gender approach in secondary education (to study drama material Lesia Ukrainka in grade 10). 
In the article gender approach is characterized in secondary education that consists both in circulating of present gender stereotypes and in advancement of ideas of gender equality. The gender analysis of dramatic poems of Lesia Ukrainian as one of facilities of correction of process of socialization is described youth depending on sex. dramatics.

Key words: gender, gender stereotypes, gender approach in education, gender aspect of study of

Сучасна наукова парадигма позначена антропоцентризмом, тому у центрі всіх наукових досліджень перебуває людська особистість, яку можна описувати в різних аспектах, зокрема, й 3 огляду на їі соціалізацію у суспільстві. На основі цього підходу було сформовано новий категоріальний апарат, що містить терміни 3 ключовим словом «гендер».

Гендер репрезентує соціальні і «культурні маски статі» у межах тих або інших соціокультурних уявлень, що закріпилися у певному суспільстві. Зокрема, літературознавча енциклопедія Ю. Коваліва розглядає поняття гендер як «рольові, зумовлені впливом соціуму особливості поведінки представників обох статей, зафіксовані у поняттях «фемінність» (жіночість) і «маскулінність» (чоловічість), тлумачення яких відрізняється від біологічного трактування статі» [ 5, с. 215].

Гендерний підхід у сучасній освіті в Україні полягає в необхідності корекції процесу соціалізації молоді залежно від статі відповідно до соціальноекономічних умов суспільства, іншими словами - у гендерній соціалізації.

Отже, актуальним стає звернення до аналізу гендерних аспектів буття людини через призму творчості видатних постатей української літератури. Зв'язок гендерних інтенцій із сучасним сприйняттям ролі жінки та чоловіка у суспільстві чітко простежується у творчості Лесі Українки.

Мета статті - охарактеризувати гендерний підхід у середній освіті на матеріалі вивчення у загальноосвітній школі драматичних поем Лесі Українки.

Про гендерні стосунки статей, гендерну просвіту та виховання (від англ. gender - стать як соціальне явище) в Україні заговорили на початку 90-х минулого століття під впливом поширення зі заходу феміністичних ідей та результатів гендерних досліджень, коли було виявлено проблему нерівності можливостей за ознакою статі при формальній юридичній рівності статей. Боротьба за соціальну рівність на початку XXI ст. полягає в тому, щоб можливості людини якомога менше визначалися чинником статі [4, с. 7].

Сучасне науково-філософське розуміння гендеру як соціокультурного явища зводиться до аналізу чотирьох взаємопов'язаних підсистем: біологічна стать, гендерні стереотипи, гендерні ролі та гендерна ідентичність.

Cmamь відноситься до універсальних біологічних відмінностей жінок і чоловіків (наприклад, тільки жінки можуть виношувати дітей).

Бути в суспільстві чоловіком чи жінкою означає не просто мати певні анатомічні особливості - це означає виконувати ті чи інші запропоновані нам гендерні ролі. Гендерні ролі - засвоєна поведінка, яка зумовлює діяльність, завдання та відповідальність, що сприймаються і як чоловічі, i як жіночі. Гендерні ролі не постійні, мінливі, різноманітні як у межах однієї 
культури, так і в різних культурах. Окрім того, гендерна роль людини у суспільстві впливає на їі гендерну ідентифікацію.

На основі гендерної ідентифікації людини виникають відповідні стереотипи. Гендерний стереотип - це спрощений, стійкий, емоційно забарвлений образ поведінки і рис характеру чоловіків і жінок. Стереотипи виявляються в усіх сферах життя: самосвідомості, міжособистісному спілкуванні, міжгруповій взаємодії. Окрім того, гендерні стереотипи закріплюють розбіжності між жінками та чоловіками, хлопчиками й дівчатками і стають перепоною до змін у їхніх стосунків. Позитивна роль гендерних стереотипів полягає у тому, що будучи звичними формами поведінки, вони допомагають орієнтуватися в реальних обставинах без докладання зусиль для пошуку рішень. Негативна - у тому, що вони спричиняють психологічний тиск на розвиток особистості чоловіка і жінки, не надають чіткого уявлення про нові реальні процеси, стримують зміни, формують несприйняття нового [3, с. 38].

Гендерна ідентичність конструюється в соціальній галузі та визначається соціально-культурними чинниками залежно від особливостей конкретного соціуму. У процесі соціальної діяльності індивід стверджує в суспільстві свій свідомо чи несвідомо сформований гендерний образ i, відповідно, бере участь у формуванні гендерного світогляду спільноти.

Освітні заклади значною мірою визначають гендерну ідентичність неповнолітніх українців, а також ті можливості особистого, громадянського та професійного вибору, що у них $є$.

Освітня галузь «Мови i літератури» $\epsilon$ одним 3 найважливіших трансляторів, з допомогою якого може відбуватися як тиражування наявних гендерних стереотипів, так i просування ідей гендерної рівності. У державному стандарті зазначено, що «формування комунікативної i літературної компетенції дітей базується на соціальних навичках, світоглядних переконаннях тощо. Поняття «соціальні навички», «світоглядні переконання» досить широкі, вони враховують i поняття «гендерної компетенції особистості дівчинки чи хлопчика» [2, с. 88].

Важливо, що в останні десятиліття постало питання як саме світогляд жінки/чоловіка-митця впливає на характер написання й сам процес творення літератури, тобто роль гендерних стереотипів у творчості письменників чоловічої та жіночої статі.

Об'єктом гендерного літературознавства науковці визначають гендерну картину світу, засновану на стереотипах маскулінності i фемінності, специфіку авторської свідомості, що визначається гендерною ідентичністю, особливу точку зору автора - чоловіка або жінки - і його героїв, жанрову систему, що також має гендерне вимірювання.

Теорія гендеру надає змогу по-новому інтерпретувати твори художньої літератури. В. Агеєва підкреслює: «Гендерний аналіз, зміщуючи акценти на індивідуально-психологічну проблематику, враховуючи часто не визнані суспільством чи панівною патріархальною ідеологією погляди, надає змогу 
виокремлювати різні рівні художнього тексту, враховувати різні ціннісні орієнтації» [1, с. 426].

У змісті творів української літератури, що вивчаються в шкільному курсі старших класів, у більшості випадків висвітлено стосунки між чоловіком і жінкою на рівні почуттів, побуту. Проте в деяких творах вже в XIX столітті письменники намагались об'єктивно розкрити роль і місце жінки в суспільстві, іiі боротьбу за права та свободу. Поступово сформувався образ сильної жінки, яка хоче знайти застосування своїм здібностям і можливостям в умовах нового життя, нових обставин (М. Хвильовий «Сентиментальна історія»), прагне жити за велінням власної душі, за своїми переконаннями і поглядами (О. Кобилянська «Людина» (Олена), «Земля» (Анна); Леся Українка «Бояриня» (Оксана); Іван Франко «Перехресні стежки» (Регіна)).

Жінка в баченні українських письменників $є$ втіленням високої духовності, добра, краси, кохання - почуттів, які надихають їі на прекрасні справи і вчинки (Леся Українка «Лісова пісня» (Мавка); М. Коцюбинський «Тіні забутих предків» (Марійка); Ліна Костенко «Маруся Чурай» (Маруся Чурай); Г. Тютюнник «Три зозулі 3 поклоном» (Марфа, Софія); Іван Багряний «Тигролови» (Наталка Сірко) та ін.).

Проте не у всіх творах української літератури кін. XIX - поч. XX ст. висвітлено проблему рівності (нерівності) чоловіка та жінки у суспільстві. Гостро до цієї проблеми підійшла Леся Українка у своїх драматичних поемах, де жінка, на відміну від традиційної гендерної ролі, стає уособленням сильної та відважної особистості, котра готова на все заради власного щастя та кохання.

Курс української літератури з прийняттям незалежності України став оновленим, цікавішим та змістовнішим. Так, внесено до шкільної програми геніальні драматичні поеми талановитої української письменниці, які раніше не вивчалися у школі.

Драматургія Лесі Українки - феноменальне явище в українській літературі: вона вражає новизною тем, гостротою соціально-психологічних конфліктів, філософськими узагальненнями і поетичною красою. У своїх драматичних творах письменниця часто зверталася до сюжетів і так званих «вічних образів», узятих із Біблії і Євангелія, з історії та літератури інших народів. Обізнана 3 історією й культурою народів Європи й Азії, вона відшукувала такі події, які були б співзвучними українській сучасності, що дозволило розширити тематичні обрії нашої драматургії, порушувати злободенні соціально-політичні й морально-етичні проблеми, які хвилювали українське громадянство.

Варто зауважити, що у своїх драматичних поемах Леся Українка порушувала проблеми, які набули актуальності й нині. До одних із важливих можна віднести такі як: місце жінки у суспільстві (феміністичні погляди), вплив світоглядних ідей обох статей на формування особистості, визначення гендерних стереотипів, що $\epsilon$ складовою вивчення гендерного підходу в літературі. 
Отже, учителю необхідно здійснювати разом із учнями гендерний аналіз драматичних творів Лесі Українки. Він містить кілька аспектів:

1) гендерна інтерпретація художнього тексту (аналіз чоловічих та жіночих персонажів, визначення характеру їх взаємовідносин, причин та наслідків гендерної дисгармонії, еволюції гендерного світогляду персонажів, проектування можливих паритетних стосунків статей);

2) гендерна позиція кожного персонажа (хто із них знаходиться на I рівні «зріла любов», на II рівні «пасивна любов» і на III рівні «деструктивна любов»);

3) аналіз рівня фізичної чи моральної деградації персонажів;

4) визначення гендерної поведінки героїв.

Завдяки гендерному аналізу драматичного твору вчитель може акцентувати увагу учнів на правильному розумінні гендерних стереотипів чоловіка та жінки у суспільстві, здійснювати гендерне виховання та сприяти розвитку моральних якостей учнів.

Так, наприклад, у 10 класі учні вивчають драму-феєрію Лесі Українки «Лісова пісня». Стандартний підхід до вивчення драматичного твору базується на традиційних основних етапах: самостійне прочитання твору учнями, обговорення змісту (сюжету) драми, обмін враженнями від прочитаного, і в результаті - один із видів аналізу («вслід за автором», подієвий, пообразний, проблемно-тематичний).

Під час вивчення драми-феєрії «Лісова пісня» у 10 класі, вчитель має зосередити увагу учнів саме на гендерних ролях (стереотипах) кожного із дійових осіб. Це надасть змогу сформувати правильне гендерне світобачення учнів.

Під час вивчення драматичної поеми «Бояриня» у 10 класі вчительсловесник має звертати увагу учнів на проблему формування гендерних ролей чоловіка та жінки у суспільстві, у такий спосіб здійснюючи гендерне виховання сучасної молоді.

Однак педагоги не використовують повною мірою потенційних можливостей гендерного виховання, закладених в змісті творів, зосереджуючи основну увагу на опануванні учнями головних сюжетних ліній, що лежать на поверхні.

Отже, гендерний аспект драматичних поем досі не висвітлено в літературознавстві. Закономірно, що сучасна тенденція переорієнтації на гендерне навчання та виховання потребує детальних досліджень заявленої теми.

\section{Література}

1. Агеєва В. Гендерна літературна теорія та критика / В. Агеєва // Основи теорії гендеру : [навч. посіб]. - К. : «К.І.С», 2004. - C.426-445.

2. Гендерні стандарти сучасної освіти : зб. рекомендацій. Частина 1. [Електронний pecypc]- Київ, 2010.- Режим доступу : http://www.vsirivni.com.ua/sites/default/files/ 2011_gender_standards_p1.pdf

3. Кікінеджі О.М. Формування гендерної культури молоді: науково-методичні матеріали до тренінгової програми : [навч. посіб.] - 2-ге вид., виправл./ О. Кікінеджі, О. Кізь. - Тернопіль : ТНПУ ім. В. Гнатюка, 2009. - 160 с. 
4. Кравець В. П. Історія гендерної педагогіки : [навч. посіб.] / В.П. Кравець. Тернопіль: Джура, 2005. - 440 с.

5. Літературознавча енциклопедія: [автор-уклад. Ю. І. Ковалів]. - К.: Академія, 2007. - T.1. $-608 \mathrm{c}$.

Стаття надійшла до редакції 12.05.2012 p.

УДК 378.621

С. О. Кононенко,

кандидат пед. наук, доиент, Кіровоградський ДПУ імені В. Винниченка

\section{ОСОБЛИВОСТІ ВИВЧЕННЯ ЕЛЕКТРОТЕХНІЧНИХ РОБІТ У 7-9 КЛАСАХ ОСНОВНОЇ ШКОЛИ}

Кононенко С. О. Особливості вивчення електротехнічних робіт у 7-9 класах основної иколи.

У статті запропоновано методику викладання електротехнічних робіт для учнів 7-9 класів під час вивчення курсу «Технологї̈» відповідно до чинної нової редакиії навчальної програми.

Ключові слова: методика, електротехніка, технології, електротехнічні роботи.

Кононенко С. А. Особенности изучения электротехнических работ в 7-9 классах основной школьь.

В статье предложена методика изучения электротехнических работ для учеников 79 классов при освоении курса «Технологии» в соответствии к действующей новой редакиии учебной программы.

Ключевые слова: методика, электротехника, технологии, электротехнические работьы.

Kononenko S. Features of the study of electrical work in grades 7-9 of basic school.

In the article the offered methodology of teaching of electrical engineering works is for students 7-9 classes at the study of course of "Technology" in accordance with the operating new release of online tutorial.

Key words: methods, electrical technology, electrical work.

Постановка проблеми. Зміст варіативної частини нової редакції шкільної навчальної програми з трудового навчання передбачає вивчення електротехнічних робіт за двома варіантами у 5-6 та 7-9 класах [2]. Це пов'язано 3 тим, що процес вивчення електротехнічних робіт має певні свої особливості.

По-перше, електротехнічні роботи займають провідне місце в системі загально-технічної підготовки учнів, оскільки в процесі їх вивчення створюються умови для виконання основних завдань трудового навчання. Успішно проводиться профорієнтаційна робота у формі бесід про професії людей, пов'язаних з електрикою. Оскільки електрична енергія знаходить широке використання в народному господарстві, то, пов'язані з нею професії $\epsilon$ досить поширеними (професії електромонтера, слюсаряелектромонтажника та інші). Розповідь про ці професії органічно вписується до змісту навчального матеріалу.

По-друге, поняття «електрична енергія» наскрізно пронизує сучасне виробництво, становить його суттєві ознаки. Тому шляхом ознайомлення 3 ним створюються уявлення про основи сучасного виробництва в цілому, тобто здійснюється реалізація політехнічного навчання. 